\title{
High-performance InP-based photodetector in an amplifier layer stack on semi-insulating substrate
}

\section{Citation for published version (APA):}

Xu, L., Nikoufard, M., Leijtens, X. J. M., Vries, de, T., Smalbrugge, E., Nötzel, R., Oei, Y. S., \& Smit, M. K. (2008). High-performance InP-based photodetector in an amplifier layer stack on semi-insulating substrate. IEEE Photonics Technology Letters, 20(23), 1941-1943. https://doi.org/10.1109/LPT.2008.2005425

DOI:

10.1109/LPT.2008.2005425

Document status and date:

Published: 01/01/2008

\section{Document Version:}

Publisher's PDF, also known as Version of Record (includes final page, issue and volume numbers)

\section{Please check the document version of this publication:}

- A submitted manuscript is the version of the article upon submission and before peer-review. There can be important differences between the submitted version and the official published version of record. People interested in the research are advised to contact the author for the final version of the publication, or visit the $\mathrm{DOI}$ to the publisher's website.

- The final author version and the galley proof are versions of the publication after peer review.

- The final published version features the final layout of the paper including the volume, issue and page numbers.

Link to publication

\section{General rights}

Copyright and moral rights for the publications made accessible in the public portal are retained by the authors and/or other copyright owners and it is a condition of accessing publications that users recognise and abide by the legal requirements associated with these rights.

- Users may download and print one copy of any publication from the public portal for the purpose of private study or research.

- You may not further distribute the material or use it for any profit-making activity or commercial gain

- You may freely distribute the URL identifying the publication in the public portal.

If the publication is distributed under the terms of Article 25fa of the Dutch Copyright Act, indicated by the "Taverne" license above, please follow below link for the End User Agreement:

www.tue.nl/taverne

Take down policy

If you believe that this document breaches copyright please contact us at:

openaccess@tue.nl

providing details and we will investigate your claim. 


\title{
High-Performance InP-Based Photodetector in an Amplifier Layer Stack on Semi-Insulating Substrate
}

\author{
Ling Xu, Student Member, IEEE, Mahmoud Nikoufard, Xaveer J. M. Leijtens, Member, IEEE, Tjibbe de Vries, \\ Elbertus Smalbrugge, Richard Nötzel, Yok Siang Oei, and Meint K. Smit, Fellow, IEEE
}

\begin{abstract}
A waveguide photodetector (PD) based on semi-insulating (SI) indium phosphide (InP) was simulated, designed, and fabricated. The layer stack for this PD was optimized for use as an optical amplifier or laser and it can be combined with the passive components. By using an SI substrate and deep etching, a small, efficient, and high-speed PD was made, which allows for easy integration of source, detector, and passive optical components on a single chip. A 3-dB bandwidth of $35 \mathrm{GHz}$ and $0.25 \mathrm{~A} / \mathrm{W}$ external radio-frequency reponsivity is measured at $1.55-\mu \mathrm{m}$ wavelength for a $1.5-\mu \mathrm{m}$-wide and $30-\mu \mathrm{m}$-long waveguide $P D$ at $-4-\mathrm{V}$ bias voltage. The polarization dependence in the responsivity is less than $0.27 \mathrm{~dB}$.
\end{abstract}

Index Terms-Photodetector (PD), semi-insulating (SI), semiconductor optical amplifier (SOA).

\section{INTRODUCTION}

$\mathbf{M}$ ONOLITHIC integration of different optical building blocks, such as passive waveguide devices (PWDs), semiconductor optical amplifiers (SOAs), photodetectors (PDs), and modulators allows for flexible design of photonic integrated circuits. Previously, we reported on devices based on a combination of PWDs and SOAs, such as multiwavelength ring lasers [1] and mode-locked lasers [2]. This letter focuses on the performance of PDs fabricated in the SOA layer stack and operated by reversely biasing the pn-junction.

Others have presented PDs with increased sensitivity by monolithic integration of a waveguide PD and an SOA in a common layer stack [3]-[5]. In [3], a PD based on bulk material has achieved 20-GHz bandwidth, and in [5] the PD was based on multiquantum-well and achieved 40-Gb/s operation. However, the latter PD is highly polarization-dependent.

In this letter, we present a $35-\mathrm{GHz}$ PD in a bulk SOA layer stack with smaller than $0.27-\mathrm{dB}$ polarization dependence in the responsivity. The active-passive layer stack used for these PDs is shown in Fig. 1. The film layer thickness of the waveguide is $500 \mathrm{~nm}$, both in the absorbing region and in the transparent region, in order to obtain single-mode operation in the transversal direction. The confinement factor multiplied by the material gain coefficient of the SOA/laser based on this layer stack is

Manuscript received May 26, 2008; revised August 14, 2008. Current version published November 14, 2008. This work supported in part by the Dutch National Broadband Photonics Access project and in part by the Dutch National Smartmix Project Memphis.

L. Xu, X. J. M. Leijtens, T. de Vries, E. Smalbrugge, R. Nötzel, Y. S. Oei, and M. K. Smit are with COBRA Research Institute, Technical University Eindhoven, 5600AZ Eindhoven, The Netherlands.

M. Nikoufard is with the Department of Electrical Engineering, Faculty of Engineering, University of Kashan, Kashan 87317-51167, Iran.

Color versions of one or more of the figures in this letter are available online at http://ieeexplore.ieee.org.

Digital Object Identifier 10.1109/LPT.2008.2005425

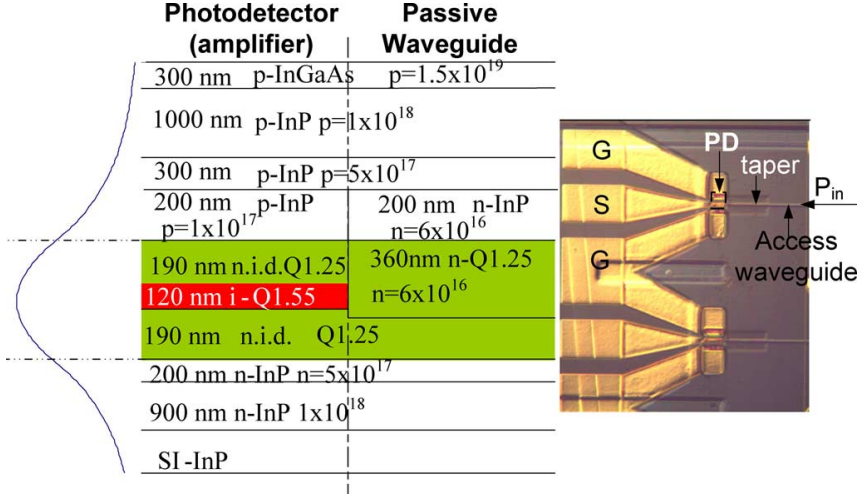

Fig. 1. (left) Active-passive butt-joint layerstack with specifications based on an SI substrate.The unit for the doping level is $\mathrm{cm}^{-3}$. (right) Top view of the fabricated PD.

$1.12 \times 10^{-20} \mathrm{~m}^{2}$ and the threshold current density is about $3 \mathrm{kA} / \mathrm{cm}^{2}$ with cleaved facets at room temperature. One example which monolithically integrates a passive component (a wavelength duplexer), an SOA, and a PD based on this layer stack is the reflective transceiver [6]. It had a 750- $\mu \mathrm{m}$-long SOA and achieved 5-dB fiber-fiber gain with $100 \mathrm{~mA}$ at the gain peak at $1530 \mathrm{~nm}$. The bandwidth of the PD was limited to $14 \mathrm{GHz}$ due to the $\mathrm{N}$-substrate and the bonding wire. To obtain a higher radiofrequency (RF) bandwidth, a semi-insulating (SI) substrate was used to reduce the RF loss and the parasitic capacitance. To futher minimize the capacitance, this PD is small and etched through the film until the highly doped N-InP layer. The fabrication technology is completely compatible with the SOA/laser and the passive components. The measurement results show that a 30- $\mu \mathrm{m}(80 \mu \mathrm{m})$-long, $1.5-\mu \mathrm{m}$-wide deeply etched PD can operate up to $35 \mathrm{GHz}(28 \mathrm{GHz})$ with external RF responsivity up to $0.25 \mathrm{~A} / \mathrm{W}(0.35 \mathrm{~A} / \mathrm{W})$ at a wavelength of $1.55 \mu \mathrm{m}$. The polarization dependence in the responsivity is less than $0.27 \mathrm{~dB}$ $(0.2 \mathrm{~dB})$.

\section{Simulation}

To estimate achievable bandwidth based on this layer stack, we calculate the transit time bandwidth $\left(f_{\mathrm{tr}}\right)$, the resistive-capacitive $(R C)$ time $\left(f_{R C}\right)$, and the total bandwidth $\left(f_{\text {total }}\right)$ as a function of the waveguide width and length. The parameters and the equations for calculating the bandwidths and the series resistance of the waveguide PD with different size are given in Table I. The calculated $f_{\text {tr }}$ for these PDs is $40 \mathrm{GHz}$. The parasitic capacitance $C_{p}$ is about $12 \mathrm{fF}$ extracted from the experiments. The simulated $R C$ time bandwidth for different widths and lengths is shown in Fig. 2(left). The total bandwidth is primarily limited by the transit time for a $30-\mu \mathrm{m}$-long below $2-\mu \mathrm{m}$-wide device. The $R C$ bandwidth is 
TABLE I

EQUATIONS AND THE PARAMETERS USED FOR THE CALCULATION

\begin{tabular}{|c|c|c|}
\hline Equations & rameters & \\
\hline $\begin{array}{l}f_{\mathrm{tr}} \approx \frac{3 \cdot 5 \cdot v_{\mathrm{tr}}}{d_{\mathrm{dep}}} \\
\frac{1}{v_{\bar{t} r}^{4}}=\frac{1}{2}\left(\frac{1}{v_{\mathrm{e}}^{4}}+\frac{1}{v_{h}^{4}}\right) \\
\frac{f_{\mathrm{RC}}}{2 \pi\left(\left(R_{\mathrm{L}}+R_{\mathrm{s}}\right) C_{\mathrm{d}}+C_{\mathrm{p}} R_{\mathrm{L}}\right)} \\
\frac{1}{f_{\mathrm{total}}^{2}}=\frac{1}{f_{\mathrm{tr}}^{2}}+\frac{\varepsilon_{\mathrm{RC}}^{2}}{f_{\mathrm{RC}}^{2}} \\
C_{\mathrm{d}}=\frac{\varepsilon_{0} \cdot A}{d_{\mathrm{dep}}} \\
R_{\mathrm{p}, \mathrm{n}}=\frac{d_{\mathrm{p}, \mathrm{n}}}{e \mu_{\mathrm{h}} N_{\mathrm{p}, \mathrm{d}} W \cdot L} \\
R_{\mathrm{gn}}=\frac{W_{\mathrm{gap}}}{e \mu_{e} N_{\mathrm{d}} d_{g n} \cdot L} \\
R_{\mathrm{c}_{\mathrm{p}, \mathrm{n}}}=\frac{\rho_{\mathrm{c}_{\mathrm{p}}, \mathrm{n}}}{W_{\mathrm{c}_{\mathrm{p}, \mathrm{n}} \cdot L} \cdot L} \\
R_{\mathrm{total}}= \\
R_{\mathrm{p}}+R_{\mathrm{n}}+\left(R_{\mathrm{gn}}+R_{\mathrm{c}_{\mathrm{n}}}\right) / 2+R_{\mathrm{c}_{\mathrm{p}}}\end{array}$ & $\begin{array}{l}v_{e} \text { and } v_{\mathrm{h}}: \text { electron and hole velocity } \\
d_{\mathrm{dep}}: \text { depletion layer thickness } \\
\varepsilon_{\mathrm{r}}: \text { relative permitivity } \\
A: \text { area of the junction } \\
L \text { and } W: \text { length and width of the device } \\
\mu_{\mathrm{e}} \text { and } \mu_{\mathrm{h}}: \text { electron and hole mobility } \\
R_{\mathrm{p}} \text { and } R_{\mathrm{n}}: \mathrm{p} \text { - and n-layer sheet resistance } \\
d_{\mathrm{p}} \text { and } d_{\mathrm{n}}: \mathrm{p}-\text { and } \mathrm{n} \text { - layer thickness in the ridge } \\
N_{\mathrm{p}} \text { and } N_{\mathrm{d}}:: \text { doping level of p- and n-InP } \\
R_{\mathrm{gn}}: \text { resistance from the ridge to } \mathrm{n} \text {-contact within } \mathrm{n}-\mathrm{InP} \\
\text { layer. } \\
W_{\mathrm{gap}}: \text { distance from the middle of the ridge to n-contact } \\
d_{\mathrm{gn}}: \text { the thickness of the unetched slab n-InP. } \\
R_{\mathrm{c}_{\mathrm{p}, \mathrm{n}}}: \text { contact resistance between the metal and } \\
\text { semiconductor material p-InGaAs and n-InP. }\end{array}$ & $\begin{array}{l}v_{\mathrm{e}}: 6.0 \times 10^{6} \mathrm{~cm} / \mathrm{s} \text {, under high electric field } \\
v_{\mathrm{h}}: 4.0 \times 10^{6} \mathrm{~cm} / \mathrm{s} \text {, under high electric field } \\
d_{\mathrm{dep}}: \text { calculated about } 550 \mathrm{~nm} \text { when the PD } \\
\text { under }-4 \mathrm{~V} \text { bias voltage. } \\
\varepsilon: 13 \\
\mu_{\mathrm{h}}: 75 \mathrm{~cm}^{2} / \mathrm{s}[7] \text { in } 1 \times 10^{18} \mathrm{~cm}^{-3} \mathrm{p} \text {-InP } \\
\mu_{\mathrm{e}}: 1500 \mathrm{~cm}^{2} / \mathrm{s}[7] \text { in } 1 \times 10^{18} \mathrm{~cm}^{-3} \mathrm{n} \text {-InP } \\
W_{\text {gap }}: 10 \mu \mathrm{m} \\
W_{\mathrm{c}_{\mathrm{p}}} \text { equal to } W \text { for p-contact and } W_{\mathrm{c}_{\mathrm{n}}} \text { is } \\
50 \mu \mathrm{m} \text { wide for n-contact } \\
\rho_{\mathrm{c}}: \text { measured } 5 \times 10^{-6} \Omega \cdot \mathrm{cm}^{2} \text { for } \\
1.5 \times 10^{19} \mathrm{~cm}^{-3} \mathrm{p}-\mathrm{InGaAs} \mathrm{contact}^{-3} \text { and } \\
1.0 \times 10^{-3} \Omega \cdot \mathrm{cm}^{2} \text { for } 1 \times 10^{18} \mathrm{~cm}^{-3} \mathrm{n}-\mathrm{InP} \\
\text { contact with } 25 \mathrm{~nm} / 75 \mathrm{~nm} / 250 \mathrm{~nm} \mathrm{Ti} / \mathrm{Pt} / \mathrm{Au} . \\
R_{\mathrm{L}}: 50 \Omega \text { load }\end{array}$ \\
\hline
\end{tabular}

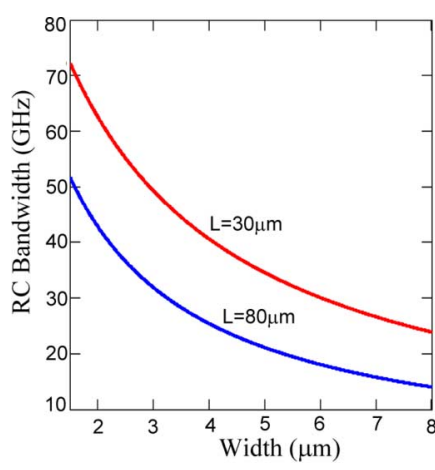

(a)

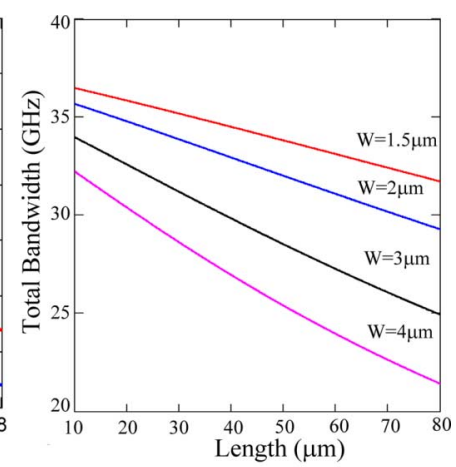

(b)

Fig. 2. Simulated $R C$ bandwidth (left) and the total bandwidth (right) based on the transit time and the $R C$ time constant for PDs with different widths and lengths. The depletion layer thickness is calculated to be $550 \mathrm{~nm}$ under $-4 \mathrm{~V}$.

the limiting factor for a device wider than $4 \mu \mathrm{m}$. The simulated total bandwidth based on the transit and $R C$ time is shown in Fig. 2(right) for different widths and lengths. Based on these results, the width of the waveguide PD was designed $1.5 \mu \mathrm{m}$ to achieve the best performance while normal optical lithography could still precisely define the waveguide. The calculated total resistance $\left(R_{\text {total }}\right)$ is about $105 \Omega(40 \Omega)$ for $30-\mu \mathrm{m}(80-\mu \mathrm{m})$ $\mathrm{PD}$, and the $R C$ bandwidth is about $70 \mathrm{GHz}(50 \mathrm{GHz})$. Therefore, the estimated total bandwidth is $35 \mathrm{GHz}(32 \mathrm{GHz})$ for $30-\mu \mathrm{m}(80-\mu \mathrm{m})$-long PD, mainly limited by the transit time. The cross-sectional view and distribution of the resistance and the capacitance of the PD is shown in Fig. 3.

To minimize the transmission loss, the access waveguide is $3 \mu \mathrm{m}$ wide, shallowly etched, linearly tapered to the deeply etched 1.5- $\mu \mathrm{m}$-wide PD.

\section{FABRICATION}

The epitaxial material was grown on an SI InP substrate by three-step low-pressure metal-organic vapor phase epitaxy at $625^{\circ} \mathrm{C}$. The first epitaxy finished with a 120 -nm-thick SOA active InGaAsP layer $\left(Q 1.55, \lambda_{\text {gap }}=1.55 \mu \mathrm{m}\right)$, embedded between two quaternary confinement layers $(Q 1.25)$ with different doping levels, covered by a 200 -nm-thick p-InP layer. Next, the active sections were defined by lithography and reactive ion etching (RIE) using a $\mathrm{SiN}_{x}$ layer as the etching mask. In the second epitaxy step, a $Q 1.25$ InGaAsP layer was selectively

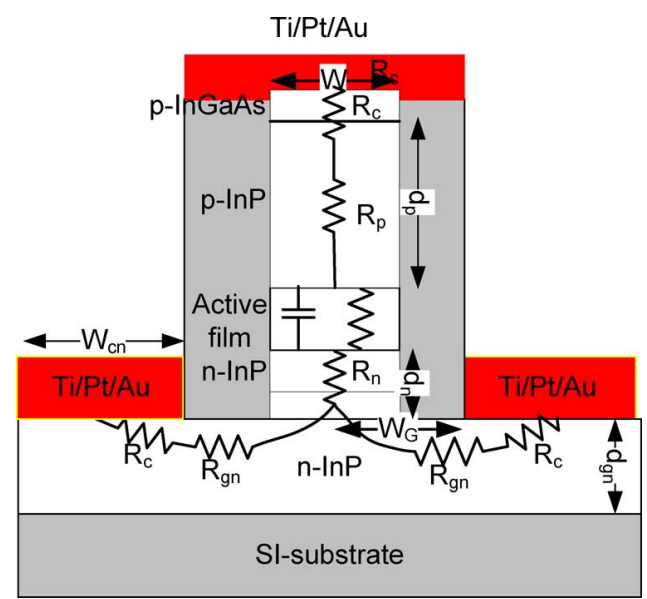

Fig. 3. Cross section of the PD and the corresponding resistance and capacitance in the PD.

grown for the passive sections with the $\mathrm{SiN}_{x}$ mask protecting the active sections. In the third epitaxy step, the p-doped InP cladding layers with graded doping level and the p-InGaAs contact layer were grown with a total thickness of $1300 \mathrm{~nm}$. The typical reflectivity at butt-joint is lower than $-40 \mathrm{~dB}$, and the transmission loss is lower than $0.19 \mathrm{~dB}$ [8]. There are four different RIE etching steps in total, the etching until the SI-substrate for the ground-signal-ground (GSG) probe pads, deep etching until highly doped n-InP layer for the PD, shallow etching until $100 \mathrm{~nm}$ into the waveguide film layer for the access passive waveguide and p-contact layer removal from the passive waveguide $(300 \mathrm{~nm})$. Polyimide was spun for passivation and planarization. Before metallization, first we etched back the polyimide in a barrel etcher to expose the p-InGaAs contact layer. Afterwards, we used photoresist as a mask to protect the exposed p-contact, and etch the polyimide directionally to open the n-InP contact layer. To form the metal contact, Ti-Pt-Au were evaporated on the top $\mathrm{p}$-InGaAs and the lateral grounds (n-InP) through lift-off. The gap distance between the $\mathrm{p}$ - and $\mathrm{n}$-contact was designed $10 \mu \mathrm{m}$. To minimize the RF transmission loss, the contacts were electro-plated until the thickness of the gold was about $1.5 \mu \mathrm{m}$, which is three times larger than the skin depth. The photograph in Fig. 1 shows fabricated PDs with metal contacts, which were tapered from the PD to the GSG 


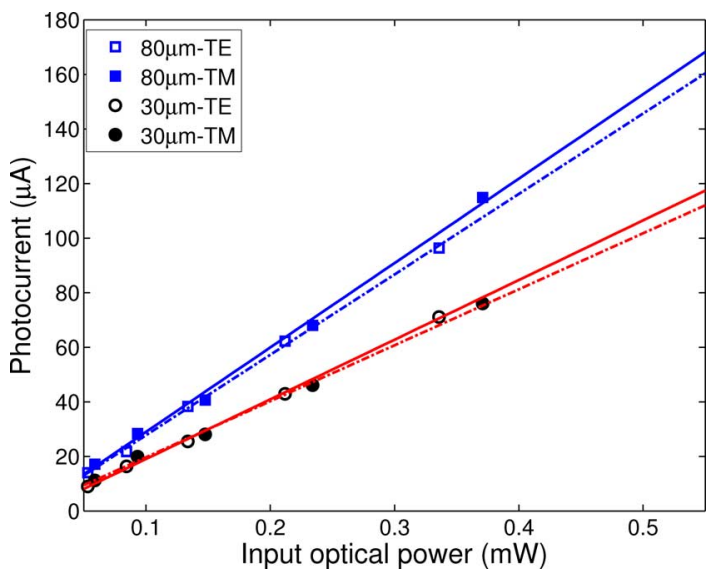

Fig. 4. Measured photocurrent of 30- and 80- $\mu$ m-long PDs for both TE and $\mathrm{TM}$ polarization as a function of the input optical power $\left(P_{\text {laser }} \times R_{\mathrm{facet}}\right)$ at $-4 \mathrm{~V}$. The straight lines are linear fits.

probe pads which have a $100-\mu \mathrm{m}$ pitch. The central contact is $70 \mu \mathrm{m}$ wide. The access side was cleaved with about $33 \%$ and $26 \%$ facet reflectivity $\left(R_{\text {facet }}\right)$ for transverse-electric (TE) and transverse-magnetic (TM) polarization.

\section{EXPERIMENTAL RESULTS}

The optical signal is coupled into the waveguide via the cleaved facet of the chip. All measurements were performed using on-wafer probing. The deeply etched PDs exhibit low dark current, less than $50 \mathrm{nA}$ at $-4-\mathrm{V}$ bias voltage for the PDs up to $80 \mu \mathrm{m}$ long. To determine the external responsivity for different polarization states, a tunable laser was used as a light source, and the polarization was selected through a polarizer and coupled through a microscope-objective to the waveguide PD. The measured photocurrents for TE and TM at $\lambda=1.55 \mu \mathrm{m}$ under $-4 \mathrm{~V}$ are shown in Fig. 4 for two different lengths. The input optical power in Fig. 4 is the power from the laser $\left(P_{\text {laser }}\right)$ multiplied by $R_{\text {facet }}$ for TE and TM polarization. The $80-\mu \mathrm{m}$-long PD has a higher responsivity than $30-\mu \mathrm{m}$-long PD. The polarization dependence in responsivity for $30-\mu \mathrm{m}$ (80- $\mu \mathrm{m}$ )-long PDs is small, less than $0.27 \mathrm{~dB}$ and $(0.2 \mathrm{~dB})$.

On-wafer $S$-parameter measurements are performed in the range of $10 \mathrm{MHz}$ to $67 \mathrm{GHz}$ with a lightwave component analyzer and a 50-GHz RF probe. The PD was biased at $-4 \mathrm{~V}$ through a $65-\mathrm{GHz}$ bias tee, and the injected wavelength from the lightwave analyzer is $1.55 \mu \mathrm{m}$ with $-1-\mathrm{dBm}$ optical power before the lensed fiber. The measured small signal frequency response (optical-electrical) is given in Fig. 5.The vertical axis is the actual responsivity relative to $1 \mathrm{~A} / \mathrm{W}$ at different frequencies. Thus the measured RF responsivity of $30-\mu \mathrm{m}(80-\mu \mathrm{m})$-long $\mathrm{PD}$ is about $0.25 \mathrm{~A} / \mathrm{W}(0.35 \mathrm{~A} / \mathrm{W})$ at $10 \mathrm{MHz}$ to $0.16 \mathrm{~A} / \mathrm{W}$ $(0.18 \mathrm{~A} / \mathrm{W})$ at $50 \mathrm{GHz}$. If we take $5 \mathrm{~dB}$ as fiber-chip coupling loss (1.5-dB uncoated facet, $3.5-\mathrm{dB}$ mode mismatching), the internal quantum efficiency is about $64 \%(89 \%)$ at $10 \mathrm{MHz}$ to $41 \%$ $(46 \%)$ at $50 \mathrm{GHz}$. The measured 3-dB total frequency response is $35 \mathrm{GHz}(28 \mathrm{GHz})$ for $30-\mu \mathrm{m}(80-\mu \mathrm{m})$-long PD, which is in good agreement with the simulated total bandwidth in Fig. 2. The oscillation in the measurement is due to the reflection between the RF probes.

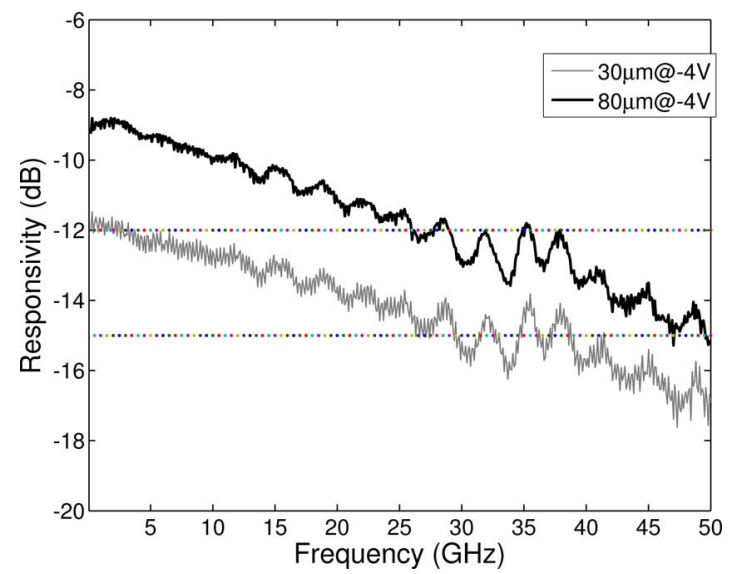

Fig. 5. Frequency response of a $30-\mu \mathrm{m}-$ long PD (gray) and an $80-\mu \mathrm{m}-$ long PD (black).

\section{CONCLUSION AND DisCUSSION}

By using an SI substrate and deep etching, a small-area waveguide PD based on an amplifier/laser layer stack achieved up to $35 \mathrm{GHz}$ with $0.25 \mathrm{~A} / \mathrm{W}$ external RF responsivity, and less than $0.27-\mathrm{dB}$ polarization dependence. This result enables the monolithic integration of source and high-performance PD based on flexible butt-joint active-passive material without the need for a dedicated detector layer stack. It will be suitable for $40-\mathrm{Gb} / \mathrm{s}$ operation.

\section{REFERENCES}

[1] J. den Besten, R. Broeke, M. van Geemert, J. Binsma, F. Heinrichsdorff, T. van Dongen, E. Bente, X. Leijtens, and M. Smit, "An integrated $4 \times 4$-channel multi-wavelength laser on InP," IEEE Photon. Technol. Lett., vol. 15, no. 3, pp. 368-370, Mar. 2003.

[2] Y. Barbarin, E. Bente, M. Heck, J. den Besten, G. Guidi, Y. Oei, J. Binsma, and M. Smit, "Realization and modeling of a $27-\mathrm{GHz}$ integrated passively mode-locked ring laser," IEEE Photon. Technol. Lett., vol. 17, no. 11, pp. 2277-2279, Nov. 2005.

[3] R. Nagarajan et al., "Multi-channel operation of a receiver photonic integrated circuit with an integrated semiconductor optical amplifier," in Proc. 33rd Eur. Conf. Opt. Commun. (ECOC'07), Berlin, Germany, Sep. 16-20, 2007, pp. 5.5.5 257-258.

[4] A. Tauke-Pedretti, M. Dummer, J. S. Barton, M. N. Sysak, J. W. Raring, and L. A. Coldren, "High saturation power and high gain integrated photoreceivers," IEEE Photon. Technol. Lett., vol. 17, no. 10, pp. 2167-2169, Oct. 2005.

[5] B. Mason, S. Chandrasekhar, A. Ougazzaden, C. Lentz, J. Geary, L. Buhl, L. Peticolas, K. Glogovsky, J. Freund, L. Reynolds, G. Przybylek, F. Walters, A. Sirenko, J. Boardman, T. Kercher, M. Rader, J. Grenko, D. Monroe, and L. Ketelsen, "Photonic integrated reciever for $40 \mathrm{Gbit} / \mathrm{s}$ transmission," Electron. Lett., vol. 38, no. 20, pp. 1196-1197, Sep. 2002.

[6] L. Xu, X. Leijtens, P. Urban, E. Smalbrugge, T. de Vries, Y. Oei, R. Nötzel, H. de Waardt, and M. Smit, "InP based monolithic integrated colorless reflective transceiver," in Proc. 14th Eur. Conf. Int. Opt. (ECIO '08), Postdeadline papers, X. Leijtens, Ed., Eindhoven, The Netherlands, Jun. 11-13, 2008, pp. FrD4, 13-16, ISBN 978-90386-1318-5.

[7] H. Neitzert, R. Fang, M. Kunst, and N. Layadi, " $\mathrm{CH}_{4} / \mathrm{H}_{2}$ reactive ion etching induced damage of InP," J. Vaccuum Sci. Technol., vol. 18, no 6, pp. 2803-2807, 2000.

[8] Y. Barbarin, E. Bente, C. Marquet, E. Leclère, T. de Vries, P. van Veldhoven, Y. Oei, R. Nötzel, M. Smit, and J. Binsma, "Butt-joint reflectivity and loss in InGaAsP/InP waveguides," in Proc. 12th Eur. Conf. Int. Opt. (ECIO '05), Grenoble, France, Apr. 6-8, 2005, pp. 406-409. 